\title{
PEMODELAN FAKTOR - FAKTOR PENYEBAB KEPARAHAN KORBAN KECELAKAAN LALU LINTAS DI KOTA AMBON DENGAN MENGGUNAKAN MODEL REGRESI LOGISTIK MULTINOMIAL
}

\section{Modeling of Factors Causing the Troubles of Traffic Accident Victims in Ambon City Using Multinomial Logistic Regression Models}

\author{
Miranti $^{1}$, F. Y. Rumlawang ${ }^{2}$, F. Kondolembang ${ }^{3 *}$ \\ 1,2,3 Jurusan Matematika, Fakultas MIPA Universitas Pattimura \\ Jln. Ir. M. Putuhena, Kampus Unpatti - Poka, Ambon, 97233, Provinsi Maluku, Indonesia
}

e-mail: ferrykondolembang@gmail.com*

\begin{abstract}
Abstrak: Kecelakaan lalu lintas merupakan salah satu penyebab utama meningkatnya angka kematian tertinggi di Indonesia. Masalah ini perlu mendapat perhatian untuk mengantisipasi jatuhnya korban meninggal dunia pada kecelakaan lalu lintas. Maka pada penelitian ini terdapat variabel respon dan beberapa variabel prediktor. Tujuan dari penelitian ini adalah untuk mengetahui apa saja faktor-faktor yang berpengaruh terhadap tingkat keparahan korban kecelakaan lalu lintas di kota Ambon berdasarkan kategori serta memodelkan tingkat keparahan korban kecelakaan lalu lintas di kota Ambon berdasarkan faktor-faktor yang signifikan menggunakan metode Regresi Logistik Multinomial. Hasil yang diperoleh yaitu faktor-faktor yang signifikan mempengaruhi tingkat keparahan korban kecelakaan lalu lintas adalah variabel jenis kelamin $\left(X_{1}\right)$, usia $\left(X_{2}\right)$, pendidikan $\left(X_{3}\right)$ dan jenis kendaraan $\left(X_{5}\right)$.
\end{abstract}

Kata Kunci: regresi logistik, regresi logistik multinomial, kecelakaan lalu lintas.

\begin{abstract}
Traffic accidents are one of the main causes of the highest increase in mortality in Indonesia. This problem needs attention to anticipate the fall of the death toll in a traffic accident. So in this study, there are response variables and several predictor variables. The purpose of this study was to find out what factors influence the severity of traffic accident victims in Ambon city based on categories and model the severity of traffic accident victims in Ambon city based on significant factors using the Multinomial Logistic Regression method. In this study, the results obtained are factors that significantly affect the severity of the traffic accident victims are sex variables $\left(X_{I}\right)$, age $\left(X_{1}\right)$, education $\left(X_{3}\right)$ and type of vehicle $\left(X_{5}\right)$.
\end{abstract}

Keywords: logistic regression, multinomial logistic regression, traffic accident.

\section{PENDAHULUAN}

Kecelakaan lalu lintas adalah kejadian dimana sebuah kendaraan bermotor tabrakan dengan benda lain dan menyebabkan kerusakan. Kadang kecelakaan ini dapat mengakibatkan luka-luka atau kematian manusia atau binatang [1].

Di Indonesia, salah satu faktor yang menjadi penyebab peningkatan jumlah angka kematian berasal dari kecelakaan lalu lintas. Berdasarkan data Kepolisian Republik Indonesia sepanjang tahun korban meninggal dunia akibat kecelakaan lalu lintas mencapai 28.000 orang sampai 38.000 orang. Jumlah 
Miranti, dkk. | Pemodelan Faktor-faktor Penyebab Keparahan ...

tersebut membuat Indonesia berada di peringkat pertama negara dengan rasio tertinggi kematian akibat kecelakaan lalu lintas di dunia [2]. Berdasarkan data yang dihimpun Polda Maluku yaitu jumlah kecelakaan lalu lintas di jalan raya pada tahun 2014 terdapat 64 orang meninggal dunia. Pada tahun 2015 terdapat 63 orang meninggal dunia. Sedangkan pada tahun 2016 terdapat 68 orang meninggal dunia [3].

Penelitian kali ini berbeda dengan penetitian yang sudah pernah dilakukan. Perbedaannya adalah adalah pada penelitian sebelumnya menggunakan metode regresi logistik ordinal yang diterapkan pada kasus kecelakaan lalu lintas di Kota Ambon tahun 2015, dimana hasil yang didapatkan yaitu berdasarkan uji kesesuaian model, faktor yang signifikan mempengaruhi tingkat keparahan korban kecelakaan lalu lintas yaitu jenis kelamin [3]. Sedangkan pada penelitian ini dilakukan dengan menggunakan metode regresi logistik multinomial dan akan diterapkan pada kasus kecelakaan lalu lintas di Kota Ambon pada tahun 2016.

Model regresi logistik merupakan bagian dari model linear umum. Model regresi logistik adalah suatu model dimana peluang respon tidak berdistribusi normal melainkan berdistribusi bernoulli, dengan ragam yang tidak homogen karena tergantung oleh peluang sukses. Regresi logistik dengan peubah respon lebih dari dua kategori yang berskala nominal disebut juga regresi logistik multinomial. Regresi logistik multinomial merupakan regresi logistik yang digunakan saat variabel dependen mempunyai skala yang bersifat multinomial dengan variabel respon berskala nominal dengan tiga kategori [4]. Berdasarkan [5] regresi logistik multinomial merupakan regresi logistik yang digunakan saat variabel dependen mempunyai skala yang bersifat multinomial dengan variabel respon berskala nominal tiga kategori.

Tujuan dari penelitian ini yaitu mendapatkan model tingkat keparahan korban kecelakaan lalu lintas di Kota Ambon dan mendapatkan faktor-faktor apa saja yang berpengaruh terhadap tingkat keparahan korban lalu lintas di Kota Ambon.

\section{METODOLOGI}

\subsection{Tipe Penelitian}

Penelitian dilakukan menggunakan data sekunder yang diperoleh dari laporan Direktorat Lalu Lintas (Ditlantas) Kepolisian Negara Republik Indonesia daerah Maluku Resort Pulau Ambon dan Pulaupulau Lease selama bulan Januari sampai Desember 2016.

\subsection{Variabel Penelitian}

Variabel-variabel yang digunakan pada penelitian ini adalah terdiri dari variabel respon $(Y)$ dan variabel prediktor $(X)$. Variabel respon yang dimaksud adalah tingkat keparahan korban kecelakaan lalu lintas. Sedangkan variabel prediktor yang digunakan berdasarkan data korban kecelakaan lalu lintas di Ditlantas Kepolisian Negara Republik Indonesia daerah Maluku Resort Pulau Ambon dan Pulau-pulau Lease Penjelasan variabel-variabel dapat dilihat pada Tabel 1.

\subsection{Prosedur Analisis}

Prosedur dalam menganalisis data pada penelitian ini adalah sebagai berikut.

1. Melakukan analisis deskriptif data untuk mengetahui karakteristik kecelakaan lalu lintas di Kota Ambon pada tahun 2016.

2. Menguji independensi data pada variabel prediktor dengan variabel respon masing-masing model. 
3. Menyusun model regresi logistik multinomial dengan langkah sebagai berikut:

a) Melakukan estimasi parameter variabel respon terhadap masing-masing variabel prediktor.

b) Membentuk fungsi logit pada masing-masing kategori variabel respon di setiap model pada tabel estimasi parameter

c) Melakukan uji serentak pada variabel prediktor terhadap model.

d) Melakukan uji parsial pada variabel prediktor yang mempunyai hubungan terhadap variabel respon pada model.

e) Melakukan uji kesesuaian model.

f) Menginterpretasi model terbaik berdasarkan kontribusi variabel prediktor yang berpengaruh terhadap variabel respon dengan menggunakan odds ratio pada masing-masing model.

g) Menghitung ketepatan klasifikasi model regresi logistik multinomial

4. Membuat kesimpulan dan saran dari hasil analisis data.

Tabel 1. Variabel Penelitian

\begin{tabular}{|c|c|}
\hline Variabel & Kategori \\
\hline \multirow{2}{*}{$\begin{array}{l}\text { Tingkat keparahan korban kecelakaan } \\
\text { lalu lintas (Y) }\end{array}$} & \multirow{7}{*}{$\begin{array}{l}1=\text { Meninggal dunia } \\
2=\text { Luka berat } \\
3=\text { Luka ringan } \\
1=\text { Laki-laki } \\
2=\text { Perempuan } \\
1=<9 \text { Tahun } \\
2=10-15 \text { Tahun } \\
3=16-25 \text { Tahun }\end{array}$} \\
\hline & \\
\hline \multirow{2}{*}{ Jenis kelamin korban $\left(\mathrm{X}_{1}\right)$} & \\
\hline & \\
\hline \multirow{7}{*}{ Usia korban $\left(\mathrm{X}_{2}\right)$} & \\
\hline & \\
\hline & \\
\hline & $4=26-35$ Tahun \\
\hline & $5=36-45$ Tahun \\
\hline & $6=46-55$ Tahun \\
\hline & $\begin{array}{l}7=>56 \text { Tahun } \\
1-s D\end{array}$ \\
\hline \multirow{4}{*}{ Pendidikan korban $\left(\mathrm{X}_{3}\right)$} & $\begin{array}{l}1=\mathrm{SD} \\
2=\mathrm{SMP}\end{array}$ \\
\hline & $3=$ SMA \\
\hline & $4=\mathrm{PT}$ \\
\hline & 5 = lain-lain \\
\hline \multirow{11}{*}{ Profesi korban $\left(\mathrm{X}_{4}\right)$} & $1=\mathrm{PNS}$ \\
\hline & $2=\mathrm{TNI}$ \\
\hline & $3=$ POLRI \\
\hline & 4=Karyawan \\
\hline & $5=$ Pelajar \\
\hline & 6=Mahasiswa \\
\hline & $7=$ Pengemudi \\
\hline & $8=$ Pedagang \\
\hline & 9=Petani \\
\hline & $10=$ Buruh \\
\hline & 11=Tidak bersekolah \\
\hline \multirow{5}{*}{ Jenis kendaraan yang terlibat $\left(\mathrm{X}_{5}\right)$} & $1=$ Sepeda motor \\
\hline & 2=Mobil penumpang \\
\hline & 3=Mobil barang \\
\hline & 4=Mobil bus \\
\hline & $5=$ Ran sus \\
\hline
\end{tabular}


Miranti, dkk. | Pemodelan Faktor-faktor Penyebab Keparahan ...

\section{HASIL DAN PEMBAHASAN}

\subsection{Analisis Deskriptif Variabel Penelitian}

Analisis deskriptif dalam penelitian ini dilakukan bertujuan untuk mengetahui gambaran atau sebaran data sehingga menghasilkan informasi yang berguna. Dalam penelitian ini, dilakukan analisis deskriptif terhadap variabel respon tingkat keparahan korban kecelakaan lalu lintas di Kota Ambon dan variabel prediktor antara lain variabel jenis kelamin $\left(\mathrm{X}_{1}\right)$, usia $\left(\mathrm{X}_{2}\right)$, pendidikan $\left(\mathrm{X}_{3}\right)$, profesi $\left(\mathrm{X}_{4}\right)$ dan jenis kendaraan yang terlibat $\left(\mathrm{X}_{5}\right)$. Jumlah sampel data penelitian yang ada sejumlah 265 orang.

\subsection{Uji Independensi}

Pengujian independensi dilakukan dengan tujuan untuk mengetahui hubungan antara dua variabel. Adapun hipotesis yang dipakai antara lain sebagai berikut:

$H_{0}$ : Tidak terdapat hubungan antara dua variabel yang diamati.

$H_{1}$ : Terdapat hubungan antara dua variabel yang yang diamati.

Daerah Kritis: Tolak $H_{0}$ jika $\chi^{2}>\chi_{(d b, \alpha)}^{2}$ atau $p$-value $<0,05$.

Tabel berikut ini merupakan hasil pengujian independensi dua variabel yang diamati yakni antara variabel respon tingkat keparahan korban kecelakaan lalu lintas di Kota Ambon dengan setiap variabel prediktor.

Tabel 2. Uji Koresponsensi

\begin{tabular}{cccc}
\hline Variabel & $\chi 2$ & P-Value & Keputusan \\
\hline Y dengan X1 & 8,300 & 0,016 & Tolak $\mathrm{H}_{0}$ \\
Y dengan X2 & 22,913 & 0,028 & Tolak $\mathrm{H}_{0}$ \\
Y dengan X3 & 18,123 & 0.02 & Tolak $\mathrm{H}_{0}$ \\
Y dengan X4 & 28,657 & 0,095 & Terima $\mathrm{H}_{0}$ \\
Y dengan X5 & 17,647 & 0,007 & Tolak $\mathrm{H}_{0}$ \\
\hline Sumber: Output SPSS 16 & &
\end{tabular}

Berdasarkan Tabel 2, terlihat variabel prediktor jenis kelamin, usia korban, pendidikan korban, dan jenis kendaraan memiliki hubungan dengan tingkat keparahan korban kecelakaan lalu lintas di Kota Ambon pada tingkat signifikan 0,05. Sedangkan untuk variabel prediktor profesi korban tidak memiliki hubungan dengan tingkat keparahan korban kecelakaan lalu lintas di Kota Ambon. Oleh sebab itu, selanjutnya dalam pemodelan regresi logistik multinomial variabel prediktor tersebut tidak diikutsertakan.

\subsection{Pemodelan Regresi Logistik Multinomial}

\subsubsection{Estimasi Parameter}

Dalam pemodelan regresi logistik multinomial ada beberapa metode yang bisa digunakan untuk mengestimasi koefisien $\beta$ salah satu diantaranya adalah metode Maximum Likelihood Estimation (MLE). Estimasi maksimum likelihood bagi koefisien $\beta$ yang diperoleh dengan metode ini menggunakan iterasi Newton Raphson. Tabel 3 menunjukkan hasil estimasi parameter model regresi logistik multinomial.

Hasil nilai estimasi parameter didapatkan model fungsi logit 1 (meninggal dunia) dan fungsi logit 2 (luka berat) sebagai berikut. Fungsi logit meninggal dunia:

$$
\begin{gathered}
g_{1}(x)=-19,922-1,971 X_{1}(1)+3,326 X_{2}(1)+1,927 X_{2}(2)+0,899 X_{2}(3)-0,271 X_{2}(4) \\
+0,418 X_{2}(5)+0,976 X_{2}(6)-2,003 X_{3}(1)-1,309 X_{3}(2)-1,875 X_{3}(3) \\
-0,905 X_{3}(4)+20,976 X_{5}(1)+16,879 X_{5}(2)+19,827 X_{5}(3)
\end{gathered}
$$


Tabel 3. Estimasi Parameter

\begin{tabular}{|c|c|c|c|c|}
\hline \multirow{3}{*}{ Variabel } & \multicolumn{2}{|l|}{ Logit 1} & \multicolumn{2}{|l|}{ Logit 2} \\
\hline & Keterangan & $\beta$ & Keterangan & $\boldsymbol{\beta}$ \\
\hline & Konstanta & 19,922 & Konstanta & $-0,298$ \\
\hline $\mathrm{X}_{1}=1$ & Jenis kelamin laki-laki & $-1,971$ & Jenis kelamin laki-laki & 0,083 \\
\hline$X_{1}=2$ & Jenis kelamin perempuan & 0 & Jenis kelamin perempuan & 0 \\
\hline $\mathrm{X}_{2}=1$ & Usia kurang dari 9 tahun & 3,326 & Usia kurang dari 9 tahun & 1,414 \\
\hline$X_{2}=2$ & Usia range 10-15 tahun & 1,927 & Usia range $10-15$ tahun & 1,458 \\
\hline$X_{2}=3$ & Usia range $16-25$ tahun & 0,899 & Usia range $16-25$ tahun & 1,177 \\
\hline $\mathrm{X}_{2}=4$ & Usia range 26-35 tahun & $-0,271$ & Usia range $26-35$ tahun & 0,487 \\
\hline$X_{2}=5$ & Usia range $36-45$ tahun & 0,418 & Usia range $36-45$ tahun & 0,617 \\
\hline$X_{2}=6$ & Usia range $46-55$ tahun & 0,976 & Usia range $46-55$ tahun & 2,105 \\
\hline$X_{2}=7$ & Usia lebih dari 56 tahun & 0 & Usia lebih dari 56 tahun & 0 \\
\hline$X_{3}=1$ & Pendidikan korban tingkat SD & $-2,003$ & Pendidikan korban tingkat SD & $-1,700$ \\
\hline$X_{3}=2$ & Pendidikan korban tingkat SMP & $-1,309$ & Pendidikan korban tingkat SMP & $-0,660$ \\
\hline$X_{3}=3$ & Pendidikan korban tingkat SMA & $-1,875$ & Pendidikan korban tingkat SMA & $-2,160$ \\
\hline$X_{3}=4$ & Pendidikan korban tingkat PT & $-0,904$ & Pendidikan korban tingkat PT & $-1,271$ \\
\hline$X_{3}=5$ & Pendidikan korban tingkat lain-lain & 0 & Pendidikan korban tingkat lain-lain & 0 \\
\hline $\mathrm{X}_{5}=1$ & Jenis kendaraan sepeda motor & 20,976 & Jenis kendaraan sepeda motor & 0,596 \\
\hline $\mathrm{X}_{5}=2$ & Jenis kendaraan mobil penumpang & 16,879 & Jenis kendaraan mobil penumpang & $-0,716$ \\
\hline$X_{5}=3$ & Jenis kendaraan mobil barang & 19,827 & Jenis kendaraan mobil barang & $-19,996$ \\
\hline $\mathrm{X}_{5}=4$ & Jenis kendaraan mobil bus & 0 & Jenis kendaraan mobil bus & 0 \\
\hline
\end{tabular}

Fungsi logit luka berat:

$$
\begin{gathered}
g_{2}(x)=0,298+0,083 X_{1}(1)+1,414 X_{2}(1)+1,458 X_{2}(2)+1,177 X_{2}(3)+0,487 X_{2}(4)+ \\
0,617 X_{2}(5)+2,105 X_{2}(6)-1,700 X_{3}(1)-0,660 X_{3}(2)-2,160 X_{3}(3)-1,271 X_{3}(4)+ \\
0,596 X_{5}(1)-0,716 X_{5}(2)-19,996 X_{5}(3)
\end{gathered}
$$

\subsubsection{Uji Serentak}

Pengujian serentak dalam model regresi logistik multinomial dilakukan dengan tujuan untuk mengetahui apakah variabel prediktor memiliki pengaruh yang signifikan terhadap tingkat keparahan korban kecelakaan lalu lintas di Kota Ambon. Adapun hipotesis yang digunakan dalam uji serentak yakni sebagai berikut:

$H_{0}: \beta_{1}=\beta_{2}=\beta_{3}=\ldots=\beta_{j}=0$

$\mathrm{H}_{1}$ : Minimal terdapat satu $\beta_{j} \neq 0$ dengan $j=1,2,3, \ldots, p$

Daerah kritis: Tolak $H_{0} G>\chi_{(d b, \alpha)}^{2}$ atau jika $p$-value $\leq \alpha(0,05)$. Hasil pengujian serentak dapat ditunjukkan pada tabel dibawah ini.

Tabel 4. Uji Korespondensi

\begin{tabular}{cccc} 
& \multicolumn{3}{c}{ Likelihood Ratio Tests } \\
\cline { 2 - 4 } Model & Chi-Square & Derajat bebas & Sig. \\
Final & 73.932 & 28 & 0.000 \\
\hline Sumber: Output SPSS 16 & & &
\end{tabular}


Miranti, dkk. | Pemodelan Faktor-faktor Penyebab Keparahan ...

Berdasarkan tabel didapatkan nilai $G$ sebesar 73,932 lebih besar dari nilai $\chi_{(d b, \alpha)}^{2}=41,337$ dan nilai p-value sebesar 0,000 lebih kecil dari nilai taraf signifikansi yang ditentukan sebesar 0,05. Hal ini berarti keputusan yang diambil adalah tolak $H_{0}$, maka dapat disimpulkan bahwa ada minimal terdapat satu atau lebih variabel bebas yang berpengaruh secara signifikan terhadap tingkat keparahan korban kecelakaan lalu lintas di Kota Ambon.

\subsubsection{Uji Parsial}

Berdasarkan hasil pengujian serentak diatas disimpulkan bahwa minimal terdapat satu atau lebih variabel prediktor yang memiliki pengaruh terhadap variabel respon penelitian. Adapun hipotesis yang dipakai dalam pengujian ini sebagai berikut:

$H_{0}: \beta_{\mathrm{j}}=0$

$H_{1}: \beta_{\mathrm{j}} \neq 0$, dimana $j=1,2, \ldots, p$

Daerah kritis: Tolak $H_{0}$ jika nilai statistik uji $W \geq Z_{\alpha / 2}$ dan jika $p$-value $\leq \alpha(0.05)$. Hasil pengujian parsial dapat ditunjukkan pada tabel berikut.

Tabel 5. Uji Wald Logit 1

\begin{tabular}{|c|c|c|c|c|}
\hline \multirow{3}{*}{ Variabel } & Keterangan & \multirow{2}{*}{$\boldsymbol{\beta}$} & \multirow{2}{*}{$\mathbf{W}$} & \multirow{2}{*}{$\mathbf{P}$} \\
\hline & Logit 1 & & & \\
\hline & Konstanta & 19,922 & 103,691 & 0,000 \\
\hline $\mathrm{X}_{1}=1$ & Jenis kelamin laki-laki & $-1,971$ & 8,092 & $0,004 * *$ \\
\hline$X_{1}=2$ & Jenis kelamin perempuan & \multicolumn{3}{|c|}{ Pembanding } \\
\hline $\mathrm{X}_{2}=1$ & Usia kurang dari 9 tahun & 3,326 & 4,773 & $0,029 * *$ \\
\hline$X_{2}=2$ & Usia range $10-15$ tahun & 1,927 & 1,809 & 0,179 \\
\hline$X_{2}=3$ & Usia range $16-25$ tahun & 0,899 & 0,481 & 0,488 \\
\hline$X_{2}=4$ & Usia range 26-35 tahun & $-0,271$ & 0,042 & 0,838 \\
\hline$X_{2}=5$ & Usia range 36-45 tahun & 0,418 & 0,111 & 0,739 \\
\hline$X_{2}=6$ & Usia range $46-55$ tahun & 0,976 & 0,530 & 0,467 \\
\hline$X_{2}=7$ & Usia lebih dari 56 tahun & \multicolumn{3}{|c|}{ Pembanding } \\
\hline $\mathrm{X}_{3}=1$ & Pendidikan korban tingkat SD & $-2,003$ & 2,181 & 0,140 \\
\hline$X_{3}=2$ & Pendidikan korban tingkat SMP & $-1,309$ & 1,102 & 0,294 \\
\hline$X_{3}=3$ & Pendidikan korban tingkat SMA & $-1,875$ & 4,754 & $0,029 * *$ \\
\hline$X_{3}=4$ & Pendidikan korban tingkat PT & $-0,904$ & 2,404 & 0,121 \\
\hline$X_{3}=5$ & Pendidikan korban tingkat lain-lain & \multicolumn{3}{|c|}{ Pembanding } \\
\hline$X_{5}=1$ & Jenis kendaraan sepeda motor & 20,976 & 155,007 & $0,000 * *$ \\
\hline$X_{5}=2$ & Jenis kendaraan mobil penumpang & 16,879 & 71,970 & $0,000 * *$ \\
\hline$X_{5}=3$ & Jenis kendaraan mobil barang & 19,827 & - & - \\
\hline$X_{5}=4$ & Jenis kendaraan mobil bus & \multicolumn{3}{|c|}{ Pembanding } \\
\hline
\end{tabular}

Berdasarkan dari tabel uji Wald yang didapatkan adalah:

i. Logit 1

a) Variabel jenis kelamin dengan kategori laki-laki berpengaruh signifikan terhadap tingkat keparahan korban kecelakaan lalu lintas di Kota Ambon.

b) Variabel usia dengan ketegori kurang dari 9 tahun berpengaruh signifikan terhadap tingkat keparahan korban kecelakaan lalu lintas di Kota Ambon.

c) Variabel pendidikan korban dengan ketegori pada jenjang SMA berpengaruh signifikan terhadap tingkat keparahan korban kecelakaan lalu lintas di Kota Ambon. 
d) Variabel jenis kendaraan yang terlibat dengan kategori sepada motor berpengaruh signifikan terhadap tingkat keparahan korban kecelakaan lalu lintas di Kota Ambon.

e) Variabel jenis kendaraan yang terlibat dengan kategori mobil penumpang berpengaruh signifikan terhadap tingkat keparahan korban kecelakaan lalu lintas di Kota Ambon.

Tabel 6. Uji Wald Logit 2

\begin{tabular}{|c|c|c|c|c|}
\hline \multirow{2}{*}{ Variabel } & Keterangan & \multirow{2}{*}{$\boldsymbol{\beta}$} & \multirow{2}{*}{$\mathbf{W}$} & \multirow{2}{*}{$\mathbf{P}$} \\
\hline & Logit 2 & & & \\
\hline & Konstanta & $-0,298$ & 0,048 & 0,827 \\
\hline$X_{1}=1$ & Jenis kelamin laki-laki & 0,083 & 0,020 & 0,889 \\
\hline$X_{1}=2$ & Jenis kelamin perempuan & & pembanding & \\
\hline$X_{2}=1$ & Usia kurang dari 9 tahun & 1,414 & 1,532 & 0,216 \\
\hline$X_{2}=2$ & Usia range $10-15$ tahun & 1,458 & 1,850 & 0,174 \\
\hline$X_{2}=3$ & Usia range $16-25$ tahun & 1,177 & 1,657 & 0,198 \\
\hline$X_{2}=4$ & Usia range $26-35$ tahun & 0,487 & 0,287 & 0,592 \\
\hline$X_{2}=5$ & Usia range $36-45$ tahun & 0,617 & 0,479 & 0,489 \\
\hline$X_{2}=6$ & Usia range $46-55$ tahun & 2,105 & 5,679 & $0,017 * *$ \\
\hline$X_{2}=7$ & Usia lebih dari 56 tahun & & pembanding & \\
\hline$X_{3}=1$ & Pendidikan korban tingkat SD & $-1,700$ & 2,181 & 0,140 \\
\hline$X_{3}=2$ & Pendidikan korban tingkat SMP & $-0,660$ & 0,474 & 0,491 \\
\hline$X_{3}=3$ & Pendidikan korban tingkat SMA & $-2,160$ & 9,798 & $0,002 * *$ \\
\hline$X_{3}=4$ & Pendidikan korban tingkat PT & $-1,271$ & 8,147 & $0,004 * *$ \\
\hline$X_{3}=5$ & Pendidikan korban tingkat lain-lain & & pembanding & \\
\hline$X_{5}=1$ & Jenis kendaraan sepeda motor & 0,596 & 0,196 & 0,658 \\
\hline$X_{5}=2$ & Jenis kendaraan mobil penumpang & $-0,716$ & 0,277 & 0,599 \\
\hline $\mathrm{X}_{5}=3$ & Jenis kendaraan mobil barang & $-19,996$ & 0,000 & - \\
\hline$X_{5}=4$ & Jenis kendaraan mobil bus & & pembanding & \\
\hline
\end{tabular}

ii. Logit 2

a) Variabel usia dengan kategori range 36-45 tahun berpengaruh signifikan terhadap tingkat keparahan korban kecelakaan lalu lintas di Kota Ambon.

b) Variabel pendidikan korban dengan kategori pada jenjang SMA berpengaruh signifikan terhadap tingkat keparahan korban kecelakaan lalu lintas di Kota Ambon.

c) Variabel pendidikan korban dengan kategori pada jenjang Perguruan Tinggi berpengaruh signifikan terhadap tingkat keparahan korban kecelakaan lalu lintas di Kota Ambon.

Berdasarkan pengujian signifikansi parameter secara parsial dari kedua model fungsi logit diatas sehingga diperoleh model fungsi logit terbaik sebagai berikut dilihat dari nilai parameter $\beta$ pada tabel dan adalah sebagai berikut.

Model fungsi logit meninggal dunia:

$g_{1}(x)=-19,922-1,971 X_{1}(1)+3,326 X_{2}(1)-1,875 X_{3}(3)+20,976 X_{5}(1)+16,879 X_{5}(2)(3)$

Model fungsi logit luka berat:

$g_{2}(x)=-0,298+2,105 X_{2}(6)-2,160 X_{3}(3)-1,271 X_{3}(4)$

\subsubsection{Uji Kesesuaian Model}

Adapun hipotesis yang digunakan dalam pengujian kesesuaian model adalah sebagai berikut: 
Miranti, dkk. | Pemodelan Faktor-faktor Penyebab Keparahan ...

$H_{0}$ : Model sesuai

$H_{l}$ : Model tidak sesuai

Daerah kritis: Tolak $H_{0}$ jika statistik uji $\chi_{\text {hitung }}^{2} \chi^{2}{ }_{(d b, \alpha)}$ atau $p$-value $<\alpha$.

Tabel 7. Uji Kesesuaian Model

\begin{tabular}{lccc}
\hline & Chi-Square & Derajat bebas & Sig. \\
\cline { 2 - 4 } Deviance & 71.415 & 64 & 0.245 \\
\hline Sumber: Output SPSS 16 & &
\end{tabular}

Berdasarkan Tabel 7. diatas diperoleh informasi bahwa nilai $\chi_{\text {hitung }}^{2}$ sebesar 71,415 lebih kecil dari nilai $\chi_{(d b, \alpha)}^{2}=83,675$ dan nilai $p$-value yakni 0,245 lebih besar dari $\alpha=0,05$ sehingga keputusan yang diambil adalah terima $H_{0}$ yang artinya model regresi logistik ordinal untuk tingkat keparahan korban kecelakaan lalu lintas di kota Ambon yang dihasilkan sudah sesuai.

\subsection{Interpretasi Odds Ratio}

Pada model regresi logistik yang di gunakan untuk interpretasi koefisien adalah odds ratio. Nilai odds ratio merupakan rasio antara kecenderungan (resiko) terjadinya suatu peristiwa dalam kelompok kasus dengan kelompok kontrol. Nilai odds ratio disajikan dalam Tabel 8.

Tabel 7. Nilai Odds Ratio

\begin{tabular}{|c|c|c|c|c|c|}
\hline Variabel Logit 1 & P-Value & $\operatorname{Exp}(B)$ & Variabel Logit 2 & P-Value & $\operatorname{Exp}(B)$ \\
\hline Konstanta & 0,000 & - & Konstanta & 0,827 & - \\
\hline $\mathrm{X}_{1}=1$ & $0,004 * *$ & 0,139 & $X_{1}=1$ & 0,889 & 1,087 \\
\hline$X_{1}=2$ & \multicolumn{2}{|c|}{ Pembanding } & $X_{1}=2$ & \multicolumn{2}{|c|}{ Pembanding } \\
\hline$X_{2}=1$ & $0,029 * *$ & 27,814 & $X_{2}=1$ & 0,216 & 4,113 \\
\hline$X_{2}=2$ & 0,179 & 6,871 & $X_{2}=2$ & 0,174 & 4,295 \\
\hline$X_{2}=3$ & 0,488 & 2,457 & $X_{2}=3$ & 0,198 & 3,246 \\
\hline$X_{2}=4$ & 0,838 & 0,762 & $X_{2}=4$ & 0,592 & 1,627 \\
\hline$X_{2}=5$ & 0,739 & 1,519 & $X_{2}=5$ & 0,489 & 1,853 \\
\hline$X_{2}=6$ & 0,467 & 2,655 & $X_{2}=6$ & $0,017 * *$ & 8,211 \\
\hline$X_{2}=7$ & \multicolumn{2}{|c|}{ Pembanding } & $X_{2}=7$ & \multicolumn{2}{|c|}{ Pembanding } \\
\hline$X_{3}=1$ & 0,140 & 0,135 & $X_{3}=1$ & 0,140 & 0,183 \\
\hline$X_{3}=2$ & 0,294 & 0,270 & $X_{3}=2$ & 0,491 & 0,517 \\
\hline$X_{3}=3$ & $0,029 * *$ & 0,153 & $X_{3}=3$ & $0,002^{* *}$ & 0,115 \\
\hline$X_{3}=4$ & 0,121 & 0,405 & $X_{3}=4$ & $0,004 * *$ & 0,280 \\
\hline$X_{3}=5$ & \multicolumn{2}{|c|}{ Pembanding } & $X_{3}=5$ & \multicolumn{2}{|c|}{ Pembanding } \\
\hline $\mathrm{X}_{5}=1$ & $0,000 * *$ & $1.287 \times 10^{-9}$ & $\mathrm{X}_{5}=1$ & 0,658 & 1,815 \\
\hline $\mathrm{X}_{5}=2$ & $0,000 * *$ & $2,141 \times 10^{-7}$ & $\mathrm{X}_{5}=2$ & 0,599 & 0,489 \\
\hline $\mathrm{X}_{5}=3$ & - & $4,081 \times 10^{-8}$ & $\mathrm{X}_{5}=3$ & - & $2,070 \times 10^{-9}$ \\
\hline$X_{5}=4$ & \multicolumn{2}{|c|}{ Pembanding } & $X_{5}=4$ & \multicolumn{2}{|c|}{ Pembanding } \\
\hline
\end{tabular}

Informasi yang dapat diperoleh dari Tabel 8 yaitu pada model fungsi logit 1 (meninggal dunia), jenis kelamin laki laki resiko mengalami tingkat keparahan kecelakaan lalu lintas meninggal dunia sebesar 0,139 kali dibandingkan jenis kelamin perempuan. Untuk usia korban kurang dari 9 tahun resiko 
mengalami tingkat keparahan kecelakaan lalu lintas meninggal dunia sebesar 27,814 kali dibandingkan usia korban lebih dari 56 tahun. Kecenderungan tingkat pendidikan korban pada jenjang SMA resiko mengalami tigkat keparahan kecelakaan lalu lintas sebesar 0,153 kali dibandingkan dengan tingkat pendidikan lain-lain, dan jenis kendaraan sepeda motor dan mobil penumpang resiko mengalami tingkat keparahan kecelakaan lalu lintas sebesar $1,287 \times 10^{-9}$ dan $2,141 \times 10^{-7}$ kali dibandingkan dengan jenis kendaraan yang lainnya. Sedangkan untuk model fungsi logit 2 (luka berat), usia korban pada range 46-55 tahun mengalami resiko tingkat keparahan kecelakaan lalu lintas meninggal dunia sebesar 8,211 kali di bandingkan usia korban lebih dari 56 tahun dan untuk tingkat pendidikan korban pada jenjang SMA dan PT resiko mengalami tingkat keparahan kecelakaan lalu lintas sebesar 0,115 dan 0,280 kali dibandingkan dengan tingkat pendidikan tidak bersekolah.

\subsection{Ketetapan Klasifikasi Model}

Berikut analisis hasil ketepatan klasifikasi dua model fungsi logit multinomial terbaik.

Tabel 7. Uji Kesesuaian Model

\begin{tabular}{lcccc}
\hline \multicolumn{1}{c}{ Observed } & \multicolumn{2}{c}{ Predicted } \\
& korban meninggal dunia & korban luka berat & korban luka ringan & Percent Correct \\
korban meninggal dunia & 13 & 27 & 5 & $28.9 \%$ \\
korban luka berat & 5 & 124 & 12 & $87.9 \%$ \\
korban luka ringan & 7 & 41 & 31 & $39.2 \%$ \\
Overall Percentage & $9.4 \%$ & $72.5 \%$ & $18.1 \%$ & $63.4 \%$ \\
$* *$ (signifikan pada 0,05)Sumber: Output SPSS 16 & & &
\end{tabular}

Berdasarkan Tabel 7, diperoleh informasi bahwa kedua model fungsi logit multinomial terbaik memprediksi klasifikasi variabel respon tingkat keparahan korban kecelakaan lalu lintas di Kota Ambon adalah sebesar $63,4 \%$. Hasil prediksi ketepatan klasifikasi yang mencapai lebih dari $50 \%$ yang berarti bahwa kedua model fungsi logit multinomial terbaik dianggap sudah cukup tepat untuk memodelkan tingkat keparahan korban kecelakaan lalu lintas di Kota Ambon.

\section{KESIMPULAN}

Dari analisis hasil dan pembahasan maka dapat disimpulkan beberapa hal yang sesuai dengan tujuan penelitian sebagai berikut.

1) Model fungsi logit multinomial terbaik untuk tingkat keparahan korban kecelakaan lalu lintas di Kota Ambon adalah sebagai berikut.

a) Model fungsi logit tingkat keparahan kecelakaan lalu lintas dengan kategori meninggal dunia: $g_{1}(x)=-19,922-1,971 X_{1}(1)+3,326 X_{2}(1)-1,875 X_{3}(3)+20,976 X_{5}(1)+16,879 X_{5}(2)$

b) Model fungsi logit tingkat keparahan kecelakaan lalu lintas dengan kategori luka berat :

$$
g_{2}(x)=-0,298+2,105 X_{2}(6)-2,160 X_{3}(3)-1,271 X_{3}(4)
$$

2) Faktor-faktor yang signifikan atau berpengaruh terhadap tingkat keparahan korban kecelakaan lalu lintas di Kota Ambon pada taraf signifikan 5\% adalah faktor jenis kelamin, faktor usia, faktor tingkat pendidikan, dan faktor penggunaan jenis kendaraan. 
Miranti, dkk. | Pemodelan Faktor-faktor Penyebab Keparahan ...

\section{DAFTAR PUSTAKA}

[1] Hosmer, D. W., dan Leweshow, Aplied Logistik Regression, New York: John Wiley dan Sons Inc, 1989.

[2] Kasim, Astrika, "Analisis Faktor-Faktor Penyebab Tingkat Kecelakaan Lalu Lintas Di Kota Ambon Dengan Metode Regresi Logistik Ordinal," Universitas Pattimura , Ambon, 2017.

[3] Meitantia, A. R, "Pemodelan Anlisis Regresi Logistik dengan Variabel Bebas Multinomial," Universitas Negeri Lampung, Lampung, 2016.

[4] Sade, Arfandi, " arfandisade," 2608 2012. [Online]. Available: http://arfandisadeas.blogspot.com/2012/08/kecelakaan-lalu-lintas.html. [Accessed 2012 2017].

[5] Tribunnews, "tribunews," tribunnews, $04 \quad 12$ 2017. [Online]. Available: https://www.tribunnews.com/otomotif/2017/12/04/data-polri-sebut-kematian-karena-kecelakaan-diindonesia-yang-tertinggi-di-dunia. [Accessed 2201 2018]. 